\title{
Clinical and genetic characterization of basal cell carcinoma and breast cancer in a single patient
}

\author{
Alessandra Morelle ${ }^{1}$, Rodrigo Cericatto ${ }^{1}$, Ana Cristina Victorino Krepischi ${ }^{2}$ and Itamar Romano Garcia Ruiz ${ }^{3^{*}}$
}

\begin{abstract}
Introduction: Multiple environmental and genetic factors are involved with the development of basal cell carcinomas (BCC), as well as with breast cancers. Tumor initiation and progression are often associated with genomic instability such as aneuploidies, and gains or losses of large chromosomal segments, known as copy number alterations (CNAs). CNAs have been successfully detected using the microarray comparative genomic hybridization technique (array-CGH) at high resolution. Data thus obtained are useful to identify specific genomic aberrations, to classify tumor stages, and to stratify subgroups of patients with different prognosis and clinical behaviors.
\end{abstract}

Case description: Clinical study of a 66-year-old white female identified two primary tumors, a ductal invasive grade-II carcinoma of the breast, and one nodular BCC. Germline and tumor genomic survey utilized the $180 \mathrm{~K}$ array-CGH analysis to investigate chromosomal alterations.

Discussion and evaluation: Several chromosomal anomalies were detected in the breast tumor genome, including focal $422 \mathrm{~Kb} 13 q 13.3$ microdeletion. In the BCC, amplification of a chromosome 6 spanning the centromere region between the cytobands $6 \mathrm{p} 23$ and $6 q 12$ was identified. Several $6 p$ amplified genes correspond to families of histone and human leukocyte antigen genes, whereas some of the CNAs found in the breast tumor are uncommon. No germline CNA was detected in the normal skin of the patient at this technical resolution.

Conclusion: CNAs found in the two different tumors of the patient constitute independent events arisen in the somatic lineage. Relevant genes to both carcinogenesis and progression are to be affected by these CNAs.

Keywords: Invasive ductal breast carcinoma; Basal cell carcinoma; Array-CGH; Copy number alterations

\section{Introduction}

Cancer establishment depends on multistep alterations of the genome including gene mutations, deletions or insertions, and epigenetics aberrations, leading to decreased apoptosis, increased cell proliferation, angiogenesis, invasion and metastasis. The tumor progression is often associated with gross genomic instability such as aneuploidies, and gains and losses of chromosomal regions.

Copy number alterations (CNAs) of DNA segments have been successfully detected by the array-CGH technique at high resolutions allowing the simultaneous investigations of thousands of genes in the entire genome. Amplification and homozygous deletions, detected by

\footnotetext{
*Correspondence: itamruiz@gmail.com

${ }^{3}$ Dermatology Department, Medical Investigation Laboratory (LIM 56), School of Medicine, University of Sao Paulo, Sao Paulo, Brazil

Full list of author information is available at the end of the article
}

array-CGH may indicate candidate oncogenes, or cancer suppressor genes, respectively.

\section{Clinical and molecular aspects}

Although BCC presumably develops from epidermal stem cells of the outer root sheet of the hair follicle, the precise origin of $\mathrm{BCC}$ is still unknown. Apart from the environmental exposure and immunosuppressive therapy, people with a fair skin type-I complexion including red or blonde hair, light colored eyes, freckling, and those with a history of intermittent sun exposure, especially ultraviolet $B$ radiation and severe sunburn during childhood, are at highest risk (Göppner and Leverkus 2011).

The estimated number of new-cases of non-melanoma skin cancer in Brazil was approximately 160,000 in 2012, the risk being 75 and 84 new cases per 100,000 for males 
and females, respectively. Rates vary across the country according to specific regions and population ethnical composition, and are particularly high in the Central, South and Southern Brazilian regions (INCA 2012).

BCCs are classified into five types: nodular-ulcerative, pigmented, sclerodeiform or fibrosing, superficial and fibroepithelioma. The nodular ulcerative is the most common form, usually isolated and affecting mainly the head and neck (Chinem and Miot 2011). Less than 1\% BCC metastasizes, mostly to lymph nodes, lungs and bones (Bader and Scarborough 2000). Treatment options are focused on local control, including surgical techniques as curettage and electrodessication, cryosurgery, surgical excision, and Mohs micrographic surgery. Nonsurgical approaches include radiotherapy, topical injection therapy, and photodynamic therapy (Rubin et al. 2005).

Mutations in genes associated with the sonic hedgehog (SHH) signaling pathway, as well as defects in repair genes or up-regulation of transcription factors have been implied in the development of BCC (Iwasaki et al. 2013). Also, several genes involved in oxidative phosphorylation and energy metabolism are up-regulated in both melanoma and BCC (Xu et al. 2012).

Germline deletions affecting the PTCH1 gene is responsible for the Gorlin syndrome phenotype also known as Nevoid Basal Cell Carcinoma Syndrome (NBCCS). A Gorlin Syndrome patient bearing 46,XY and a de novo del(9) (q22.3q31.3) was reported (Chen et al. 2006). This deletion that was detected on array-CGH analysis besides other techniques, led to the heterozygous loss of the PTCH1 gene (9q22.3). Another case also showed deletion on the 9q arm [46,XX,del(9)(q22.1q22.32)], including the PTCH1 and ROR2 genes: A 12 year old girl exhibited several NBCCS features but no tumors yet, since BCCs usually manifest after puberty (Nowakowska et al. 2007). Similarly, a 46,XY patient who showed abnormal non-Gorlin features in early age, and exhibited a de novo deletion in this same region encompassing the PTCH1 gene was described (de Ravel et al. 2009). Recent study on basaloid squamous cell carcinomas (SCC) and carcinosarcoma, which are set apart from classical SCC, detected CNAs gains in chromosomes $2 \mathrm{p}, 7 \mathrm{q}, 11 \mathrm{q}$, and losses at 13q31ter (Schaefer et al. 2011).

Regarding breast cancer, about one million new cases per year are referred worldwide, from which $35 \%$ patients will eventually die. In Brazil, the estimative of new breast cancer cases in 2012 was 52,680 and 12,705 deaths (INCA 2012). Breast cancer is a heterogeneous disease with histological differences within tumors and between patients. The cancer development in the normal mammary gland depends on stem cells, neighboring cells, including fat cells and fibroblasts that play distinct roles through specific signaling pathways (Ercan et al. 2011).
Several factors have been associated with an increased risk of breast cancer, such as family history, nulliparity, early menarche, advanced age, and a personal history of in situ or invasive breast cancer. Of all women with breast cancer, 5 to $10 \%$ may have a germline mutation of the genes BRCA1 and BRCA2 (Blackwood and Weber 1998). The estimated lifetime risk of developing breast cancer for women with $B R C A 1$ and $B R C A 2$ mutations is $40 \%$ to $85 \%$ (Frank et al. 1998).

The treatment of breast cancer includes surgery, radiation therapy, chemotherapy, and hormone therapy. The prognosis and selection of therapy may be influenced by clinical and pathological features, such as age, menopausal status, stage disease, histological and nuclear grade, hormone receptor status, over expression of human epidermal growth factor 2 (HER2/neu) and proliferative capacity of the tumor (Simpson et al. 2000). Molecular profiling has led to the classification of breast cancer into five distinct subtypes: basal-like, HER2+, normal, luminal A and luminal B (Perou et al. 2000; Sørlie et al. 2001). Pathological and molecular markers as well as gene expression profiles are useful to estimate the risk of breast cancer recurrence after surgery.

The array-CGH technology has been used to identify subgroups of patients with different prognosis and clinical behaviors, as well as to discover susceptibility genes, oncogenes and tumor suppressor genes. Distinct array-CGH profiles were described for ductal and lobular, tubular/tubulo lobular, medullary, micropapillary and secretory breast carcinomas. Loss of $16 \mathrm{q}$ has been associated with good prognosis, being more common in lobular than ductal carcinomas. Chromosome $8 \mathrm{p} 11-12$ (about $10 \mathrm{Mb}$ ) is a gene-dense region that has been implicated in various tumor types. BRCA1mutated, BRCA2-mutated, and sporadic breast tumor classes presented loss of chromosome arm 8p, and gain of arm 8q (Didraga et al. 2011). Amplification of 8p11-12, $11 \mathrm{q} 13-14$, and 20q13 was correlated with poor prognosis (Climent et al. 2007).

Twenty-three female patients bearing breast cancer, eleven of them with more than one primary tumor type, were studied (Silva et al. 2012). Four out of the eleven breast cancer patients beard a skin cancer. The BRCA1, BRCA2 and TP53 genes studied by the MLPA technique showed no CNAs in the germline (blood DNA), except for a single breast cancer patient. A micro deletion flanked by repetitive $A l u$ sequences in the BRCA1 gene at $17 \mathrm{q} 21.31$ was detected by array-CGH profile and sequencing.

In the present report, a BCC and a breast carcinoma, developed simultaneously in two different areas of the skin of a patient, were clinically and genetically characterized. The array-CGH analysis detected different somatic CNAs in both tumors, but not in the normal tissue. 


\section{Material}

The clinical diagnosis and history of the 66 year old female patient comprise an ulcerative lesion on the left dorsum that evolved within about 3 years. Another ulcerative lesion developed on the right breast within about 2 years. The menarche and menopause were attained when the patient was 13 and 55 year old, respectively. Hormonal replacement was carried out for more than 10 years. The patient's sister died due to cutaneous melanoma.

\section{Method}

Genomic DNA was isolated from fresh frozen samples of the breast cancer and the BCC, labeled with fluorescence and cohybridized with normal reference DNA. MicroarrayComparative Genome Hybridization analysis was performed as previously described (Krepischi et al. 2012) using a whole-genome $180 \mathrm{~K}$ platform (Agilent Technologies, Santa Clara, California, USA), containing about 180,000 oligonucleotides throughout the human genome, according to the manufacturer's instructions. A gain or loss in copy number was considered when the $\log _{2}$ ratio of the Cy3/Cy5 intensities of a given genomic segment was $>0.3$ or $<-0.3$, respectively. A commercially available pool of female DNAs (Promega, Madison, WI, USA) was used as the reference DNA in the array-CGH experiments.

\section{Results and discussion}

\section{Clinical analysis}

The mammography revealed a speculated nodule with high radio sensitivity, associated to skin retraction, at the upper internal right breast. The echography showed a $2.6 \mathrm{~cm}$ tumor that reached the skin and pectoral muscle. Adjacent to this nodule, another one was identified within $1.4 \mathrm{~cm}$ from the former, which exhibited similar characteristics and measured $2.0 \mathrm{~cm}$, attaining also the pectoral muscle.
Biopsies revealed an adenoid BCC lesion at the left dorsum (Figure 1); and a ductal invasor carcinoma (histological degree II; accentuated formation of tubules; moderate mitotic index; macroscopic metastasis in lymph nodes; and angio lymphatic invasion) at the right breast that infiltrated the skin, compatible with a primary breast cancer (Figure 2). The patient was submitted to neoadjuvant chemotherapy protocol AC and both lesions were surgically resected. Further, adjuvant radiotherapy and electrons beam were used at the left dorsum. The patient started the adjuvant treatment for the breast carcinoma with hormonal blocking via oral anastrosole $1 \mathrm{mg} /$ day, and till now has no evidence of neoplasia activity.

\section{Molecular array-CGH profile in BCC}

A genomic gain in the BCC sample affected about 53 $\mathrm{Mb}$ of the chromosome 6 mapped to $6 \mathrm{p} 23-\mathrm{q} 12$, at chr6: 14838756-68055170 (Genome Build Hg18) (Figure 3; Additional file 1: Figure S1). The affected region exhibit distinct levels of gain, one of them compatible with a moderate amplification. Many genes are found in this region (Additional file 2: Table S1), some of them already associated with cancer, such as the tumor suppressor gene $C D K N 1 A$, at $6 \mathrm{p} 21.2$.

The amplifications found at $6 \mathrm{p} 21.3$ attained particularly the histone cluster $1 \mathrm{H} 1 \mathrm{~d}$ gene family (HIST1H1D) responsible for chromosome structure and function, and the great number of genes encoding several classes of the major histocompatibility complex antigens $(H L A)$. There are 173 genes at the end of the $6 \mathrm{p} 23-\mathrm{p} 11$ which are repeated in the $6 \mathrm{p} 21.2-\mathrm{p} 11.2$. This pericentromeric gain in the chromosome 6 suggests that the gain/amplification may be carried by the tumor genome as a ring chromosome containing the affected sequence.

The specific gene PTCH1 was also investigated, but no alterations were found at the resolution used $(\sim 4 \mathrm{~Kb})$.

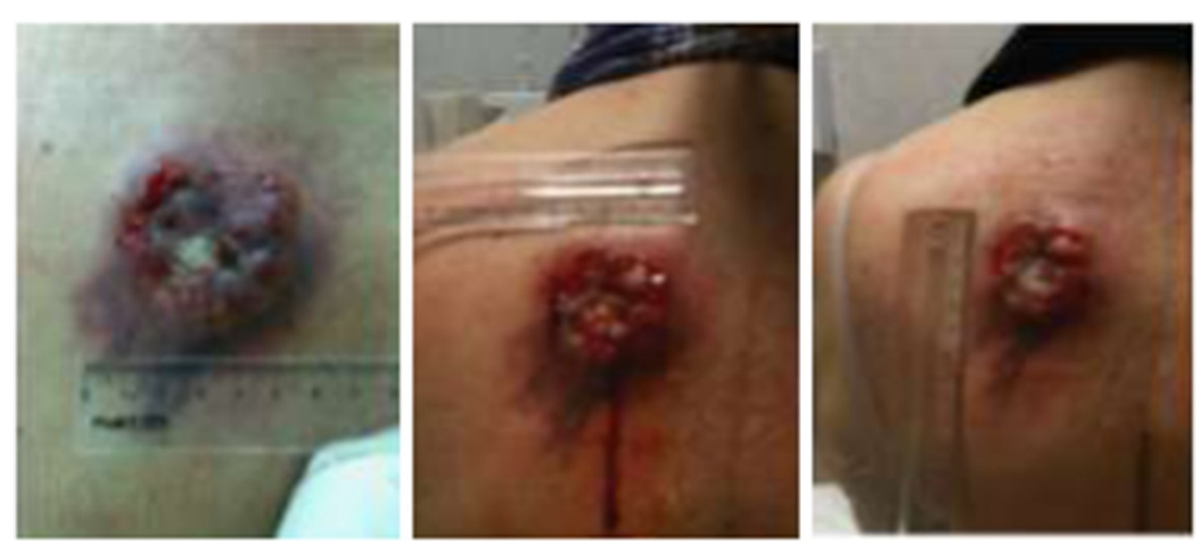

Figure 1 The ulcerative lesion developed on the left dorsum was further identified in the biopsy as an adenoid BCC. 

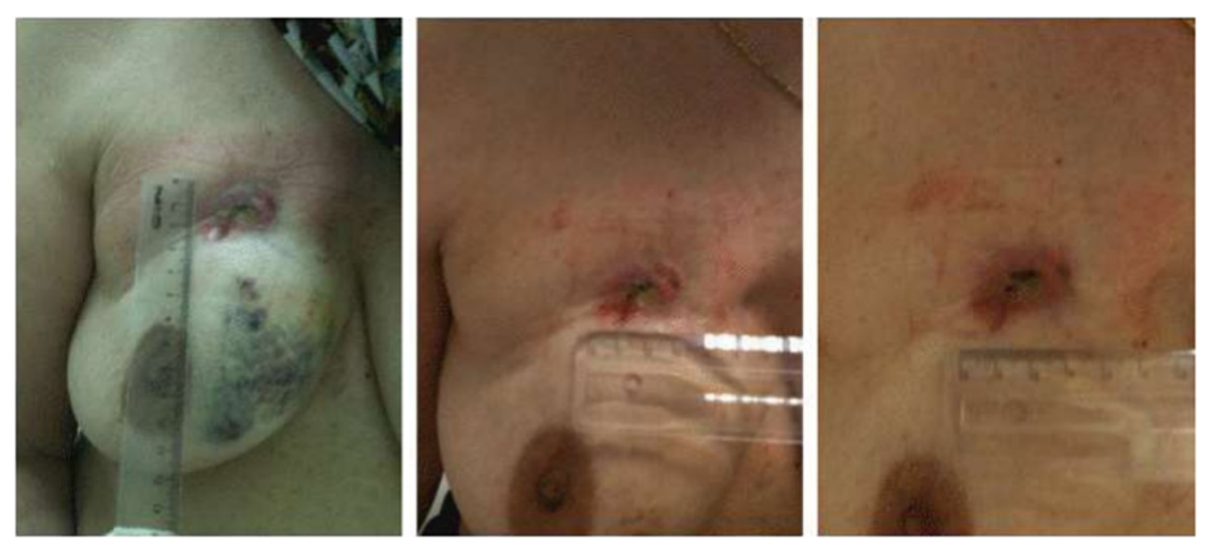

Figure 2 Ductal invasion carcinoma at the right breast is compatible with a primary breast cancer. The tumor with histological degree II, showed accentuated formation of tubules, moderate mitotic index, macroscopic metastasis in lymph nodes, angio lymphatic invasion and infiltration of the skin.

Although the chromosome 6 is often deleted in skin cancers, array-CGH studies have also shown chromosome 6 gains in SCC (Li et al. 2010; Li et al. 2012), melanoma (Pirker et al. 2010) and Merckel carcinoma (Paulson et al. 2009). Small supernumerary marker chromosomes and also ring chromosomes have been found in several instances as derived from chromosome 6 (Huang et al. 2012; Guilherme et al. 2012). Deletions at the end of both arms of one allele 6 are often involved in this rare de novo event. The presence of a large amount of euchromatin extending beyond distal 6p12.1 and proximal 6q12 (ring chromosome) has been associated with an abnormal phenotype on a girl 46,XX,r(6)(p25q27) (Ciocca et al. 2013).

\section{Molecular array-CGH profile in breast carcinoma}

Contrarily to the genome alterations observed in the BCC, which were restricted to $6 \mathrm{p}$, a great number of CNAs affecting several chromosomes (Figure 3; Additional file 3: Figure S2) and genes (Additional file 2: Table S1) were identified in the breast carcinoma. The alterations include a total loss of whole chromosome 22, and partial aneuploidy of large chromosomal regions at 4p, 4q, 6q, and $17 p$, some exhibiting a complex genomic pattern. A submicroscopic focal deletion $\sim 422 \mathrm{~Kb}$ was found at $13 \mathrm{q} 13.3$ and affected only three genes: LINC00547 (long intergenic non-coding RNA 547); TRPC4 (transient receptor potential cation channel, subfamily $\mathrm{C}$, member 4); and POSTN. The POSTN gene encodes the osteoblast specific factor periostin that is associated with cellular adhesion; it is expressed in normal breast tissue, and is up regulated in breast cancer (Zhang et al. 2010).

Specific $B R C A 1 / B R C A 2$ genes were also investigated, but no alterations were detected.

Breast cancer tissues often show alterations in chromosomes 13q and/or 22 (Climent et al. 2007; Li et al. 2009; Li et al. 2010; Didraga et al. 2011). Among the array-CGH imbalances detected in 75\% invasive ductal carcinoma breast cancer samples, there was chromosomal loss of $13 q$ in 3 cases with lymph node metastasis, besides chromosomal gains of $+1 \mathrm{q},+17 q$, and $+8 \mathrm{q}$ (Ghaffari et al. 2008). Loss of the 13q14 region was also detected in benign mammary and vaginal myofibroblastomas (Magro et al. 2012). Deletions detected at 13q and 14q were proposed as hallmarks of BRCA2-mutant tumors (Rouault et al. 2012). Besides being the $B R C A 2$ gene locus (13q12), the 13q region harbors the tumor suppressor gene $R B 1$ and the gene encoding the transcription factor FOXO1.

The $17 \mathrm{p}$ arm harbors among several other genes, the TP53 tumor suppressor gene and HIC1 (zinc-finger protein hypermethylated in cancer 1) gene, at 17p13.1 and $17 \mathrm{p} 13.3$, respectively, that were deleted in the present breast tumor sample.

Losses in chromosome 22 ranged from the whole $22 q$ to the gain of just a few hundred $\mathrm{kb}$ in $11 \%$ of breast cancers, besides several imbalances present in other samples (Benetkiewicz et al. 2006). A candidate tumor suppressor gene $M Y O 18 B$ was located in this region (Yanaihara et al. 2004). One subgroup of breast tumors without known $B R C A 1$ and $B R C A 2$ mutations showed specific gain of the 22 chromosome (Didraga et al. 2011). Similarly to the findings in the present study, loss of $4 \mathrm{q}, 6 \mathrm{q}$, and $13 \mathrm{q}$ were detected.

No deletions or duplications $>300 \mathrm{~kb}$ were identified in the normal tissue of the patient. Specific investigation concerning BRCA1 (at $\sim 20 \mathrm{~Kb}$ resolution), BRCA2 and PTCH1 (at $\sim 4 \mathrm{~Kb}$ resolution) genes did not detect submicroscopic duplications or deletions in the control sample.

\section{Conclusion}

The CNAs occurred independently in both BCC and breast cancer and none of them was present in the normal 
$\mathbf{a}$

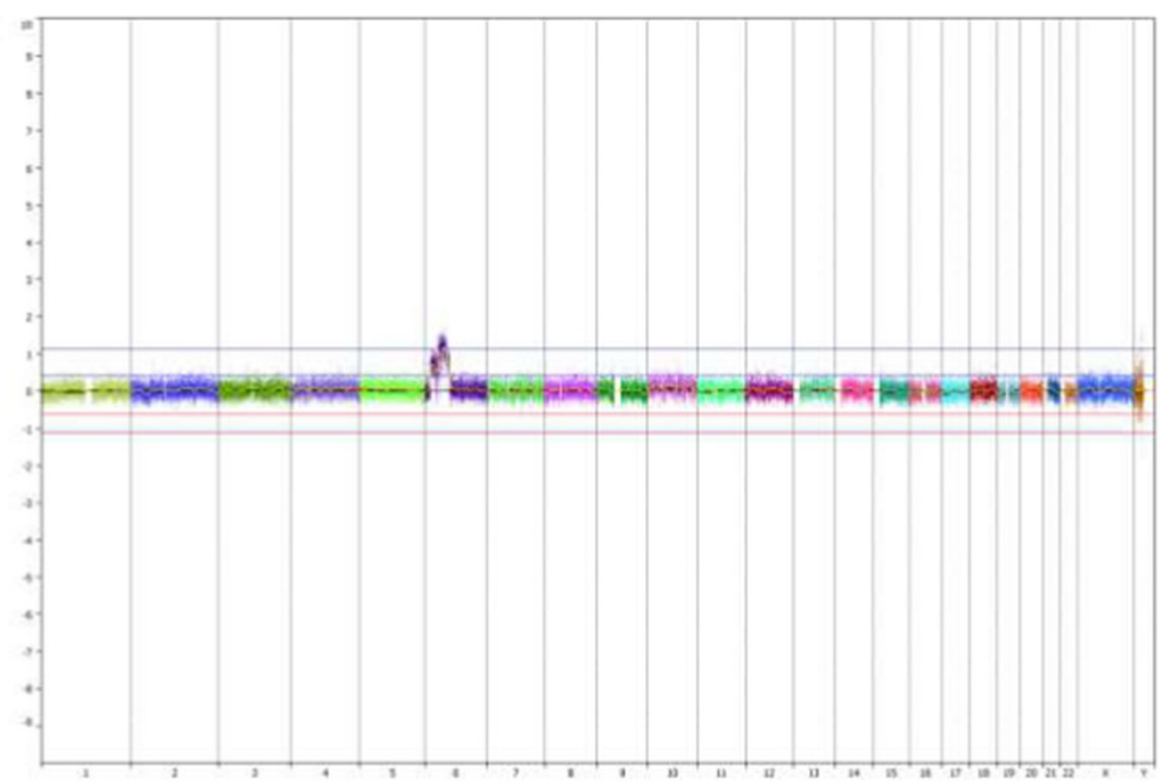

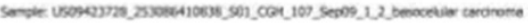

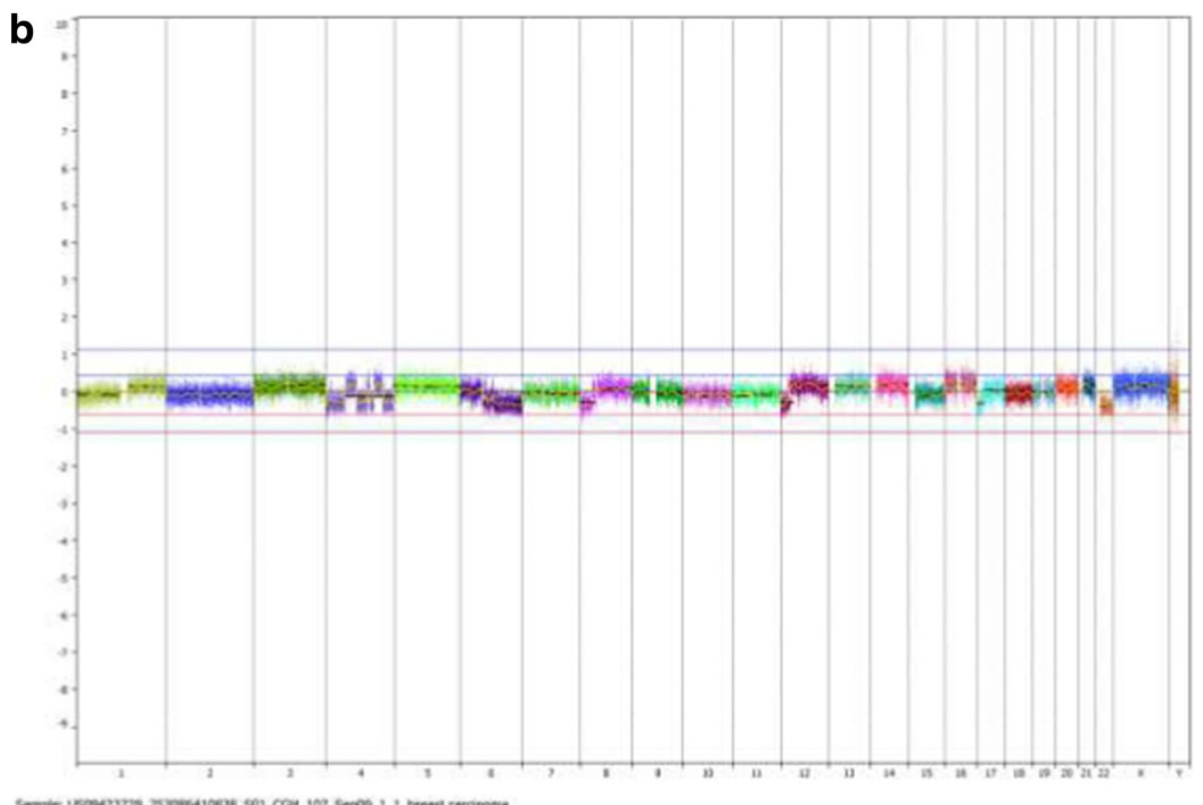

Figure 3 CNAs in whole BCC and breast cancer genomes are shown. a. The single amplification found was located at chromosome $6 p$ of the BCC sample. $\mathbf{b}$. Several chromosomes were attained by deletions in the breast carcinoma.

tissue studied. The putative ring or supernumerary marker in the BCC sample (6p21.3 gain) contains the histone cluster $1 \mathrm{H} 1 \mathrm{~d}$ gene family, whose super dosage may have affected the modeling of local chromatin with wide consequences on deregulation of genes activity. In addition, the duplication of great number of genes encoding several classes of the MHC antigens may have contributed to the BCC genesis. Regarding the complex genomic pattern of the breast tumor, haplo insufficiency of suppressor genes could play a role in the development and progression of this disease.

\section{Consent}

This study was approved by the institutional ethics committee of the Moinhos de Vento Hospital, Porto Alegre, RS, Brazil (Protocol number 374.454, August $21^{\text {st }} .2013$ ), and the patient has given an informed consent for the research and publication of this study and any accompanying 
images. DNA samples were obtained from patient's biopsies from normal breast tissue, breast tumor and BCC.

\section{Additional files}

Additional file 1: Figure S1. Array-CGH profile of the chromosome 6 from the BCC genome (Agilent $180 \mathrm{~K}$ microarray; Genomic Workbench software). The $Y$ axis corresponds to $\log _{2}$ values of the ratios between sample (Cy3) and reference DNA (Cy5). A pericentromeric gain at $6 \mathrm{p} 23-\mathrm{q} 12$ can be easily visualized in the chromosome 6 ideogram (blue bars), ranging from chr6: 14838756-68055170 (Genome Build $\mathrm{Hg} 18$ ). This pericentromeric pattern of genomic gain suggested a rearrangement structure of a ring chromosome.

Additional file 2: Table S1. Genes involved in DNA loss in breast cancer and gain in BCC samples from the patient studied. Deletion of some gene families could be particularly involved in the development of the breast cancer through haplo insuficiency, as zinc fingers transcription factors (ZNF), ubiquitin specific peptidases (USP), breast cancer 1A-complex subunit Abraxas (FAM), besides other important genes, as CDKN2AIP, CASP3, TP53, BCL2L13, BID, NFKB1, and TIMP3. In the BCC, a segment of genes present in the 6p23-p11 is repeated at the 6p21.2-p11.2. Some gene families particularly involved in the amplification, as histones (HIST) and major histocompatibility antigens (HLA), were identified as well as other genes located in the affected area, as CDKN1A and VEGFA.

Additional file 3: Figure S2. Array-CGH profiles from the breast cancer genome showing CNAs (Agilent $180 \mathrm{~K}$ microarray; Genomic Workbench software). The $Y$ axis corresponds to $\log _{2}$ values of the ratios between sample (Cy3) and reference DNA (Cy5). a. Array-CGH profile of the chromosome 4: the dark gray bars point to the $4 p$ and $4 q$ genomic segments that exhibited losses (.jpg $118 \mathrm{~K}$ ). b. Array-CGH profile of the chromosome 6: the dark gray bars point to $6 \mathrm{q}$ genomic regions that exhibited losses (.jpg $118 \mathrm{~K})$. c. Array-CGH profile of the chromosome 17: the dark gray bar indicates a deleted area of $17 p$ (.jpg 111 K). d. Array-CGH profile of the chromosome 22 showing a whole chromosome aneuploidy (loss) (.jpg $100 \mathrm{~K}$ ). e. A focal $\sim 22 \mathrm{~kb}$ micro deletion at 13q13.3 is detailed (shaded dark gray bar); below are indicated the RefSeq genes mapped in the affected genomic region (.jpg $87 \mathrm{~K}$ ).

\section{Competing interests}

The authors declare that they have no competing interests.

\section{Authors' contributions}

$\mathrm{AM}$ and RC carried out diagnosis and tumors surgery. ACVK was responsible for the array-CGH genetic study of samples. IRGR coordinated the draft of the manuscript in collaboration with AM and ACVK. All authors read and approved the final manuscript.

\section{Acknowledgement}

We are indebted to the patient who consented to participate in this study.

\begin{abstract}
Author details
'Moinhos de Vento Hospital, Porto Alegre, RS, Brazil. ${ }^{2}$ International Center for Research and Training, A. C. Camargo Cancer Hospital/National Institute of Science and Technology in Oncogenomics; Biosciences Institute, Genetics and Evolutionary Biology, Sao Paulo, Brazil. ${ }^{3}$ Dermatology Department, Medical Investigation Laboratory (LIM 56), School of Medicine, University of Sao Paulo, Sao Paulo, Brazil.
\end{abstract}

Received: 17 February 2014 Accepted: 14 August 2014

Published: 22 August 2014

\section{References}

Bader RS, Scarborough DA (2000) Surgical pearl: intralesional electrodessication of sebaceous hyperplasia. J Am Acad Dermatol 42(1 Pt 1):127-128

Benetkiewicz M, Piotrowski A, Díaz De Ståhl T, Jankowski M, Bala D, Hoffman J, Srutek E, Laskowski R, Zegarski W, Dumanski JP (2006) Chromosome 22 array-CGH profiling of breast cancer delimited minimal common regions of genomic imbalances and revealed frequent intra-tumoral genetic heterogeneity. Int J Oncol 29:935-945

Blackwood MA, Weber BL (1998) BRCA1 and BRCA2: from molecular genetics to clinical medicine. J Clin Oncol 16(5):1969-1977

Chen CP, Lin SP, Wang TH, Chen YJ, Chen M, Wang W (2006) Perinatal findings and molecular cytogenetic analyses of de novo interstitial deletion of $9 \mathrm{q}$ $(9 q 22.3 \rightarrow q 31.3)$ associated with Gorlin syndrome. Prenat Diagn 26:725-729

Chinem VP, Miot HA (2011) Epidemiology of basal cell carcinoma. An Bras Dermatol 86(2):292-305

Ciocca L, Surace C, Digilio MC, Roberti MC, Sirleto P, Lombardo A, Russo S, Brizi V, Grotta S, Cini C, Angioni A (2013) Array-CGH characterization and genotype-phenotype analysis in a patient with a ring chromosome 6 . BMC Med Genom 6:3

Climent J, Garcia JL, Mao JH, Arsuaga J, Perez-Losada J (2007) Characterization of breast cancer by array comparative genomic hybridization. Biochem Cell Biol 85:497-508

de Ravel TJ, Ameye L, Ballon K, Borghgraef M, Vermeesch JR, Devriendt K (2009) Early detection of chromosome 9q22.32q31.1 microdeletion and the nevoid basal cell carcinoma syndrome. Eur J Med Genet 52:145-147

Didraga MA, van Beers EH, Joosse SA, Brandwijk KIM, Oldenburg RA, Wessels LFA, Hogervorst FBL, Ligtenberg MJ, Hoogerbrugge N, Verhoef S, Devilee P, Nederlof PM (2011) A non-BRCA1/2 hereditary breast cancer sub-group defined by aCGH profiling of genetically related patients. Breast Cancer Res Treat 130:425-436. doi:10.1007/s10549-011-1357-x

Ercan C, van Diest PJ, Vooijs M (2011) Mammary development and breast cancer: the role of stem cells. Curr Mol Med 11:270-285

Frank TS, Manley SA, Olopade OI, Cummings S, Garber JE, Bernhardt B, Antman K, Russo D, Wood ME, Mullineau L, Isaacs C, Peshkin B, Buys S, Venne V, Rowley PT, Loader S, Offit K, Robson M, Hampel H, Brener D, Winer EP, Clark S, Weber B, Strong LC, Thomas A (1998) Sequence analysis of BRCA1 and BRCA2: correlation of mutations with family history and ovarian cancer risk. J Clin Oncol 16(7):2417-2425

Ghaffari SR, Sabokbar T, Pour PN, Dastan J, Mehrkhani F, Shoraka S, Mohagheghi MA, Tirgari F, Mosavi-Jarrahi A (2008) Comparative genomic hybridization (CGH) analysis of chromosomal aberrations in Iranian patients with invasive ductal carcinoma breast cancer. Asian Pac J Cancer Prev 9(1):66-70

Göppner D, Leverkus M (2011) Basal cell carcinoma: from the molecular understanding of the pathogenesis to targeted therapy of progressive disease. J Skin Cancer doi:10.1155/2011/650258

Guilherme RS, Klein E, Venner C, Hamid AB, Bhatt S, Melaragno MI, Volleth M, Polityko A, Kulpanovich A, Kosyakova N, Liehr T (2012) Human ring chromosomes and small supernumerary marker chromosomes - do they have telomeres? Chromosome Res 20:825-835

Huang B, Pearle P, Rauen KA, Cotter PD (2012) Supernumerary marker chromosomes derived from chromosome 6: Cytogenetic, molecular cytogenetic and array-CGH characterization. Am J Med Genet Part A 158A:1568-1573

INCA (2012) Brazilian National Institute of Cancer. www.inca.gov.br/

Iwasaki H, Nakano K, Shinkai K, Kunisawa Y, Hirahashi M, Oda Y, Onishi H, Katano M (2013) Hedgehog GLI3 activator signal augments tumorigenicity of colorectal cancer via up-regulation of adherence-related genes. Cancer Sci 104(3):328-336. doi:10.1111/cas.12073. Epub 2013 Jan 10

Krepischi AC, Achatz MI, Santos EM, Costa SS, Lisboa BC, Brentani H, Santos TM, Gonçalves A, Nóbrega AF, Pearson PL, Vianna-Morgante AM, Carraro DM, Brentani RR, Rosenberg C (2012) Germline DNA copy number variation in familial and early onset breast cancer. Breast Cancer Res 14(1):R24

Li J, Wang K, Li S, Timmermans-Wielenga V, Rank F, Wiuf C, Zhang X, Yang H, Bolund L (2009) DNA copy number aberrations in breast cancer by array comparative genomic hybridization. Genomics Proteomics Bioinformatics $7(1-2): 13-24$

Li J, Wang K, Jensen TD, Li S, Bolund L, Wiuf C (2010) Tumor heterogeneity in neoplasms of breast, colon, and skin. BMC Res Notes 3:321-330

Li J, Wang K, Gao F, Jensen TD, Li ST, DeAngelis PM, Kølvraa S, Proby C, Forslund O, Bolund L, Clausen OP (2012) Array comparative genomic hybridization of keratoacanthomas and squamous cell carcinomas: different patterns of genetic aberrations suggest two distinct entities. J Invest Dermatol 132:2060-2066

Magro G, Righi A, Casorzo L, Antonietta T, Salvatorelli L, Kacerovská D, Kazakov D, Michal M (2012) Mammary and vaginal myofibroblastomas are genetically related lesions: fluorescence in situ hybridization analysis shows deletion of $13 q 14$ region. Hum Pathol 43(11):1887-1893 
Nowakowska B, Kutkowska-Kaźmierczak A, Stankiewicz P, Bocian E, Obersztyn E, Ou Z, Cheung SW, Cai WW (2007) A girl with deletion 9q22.1-q22.32 including the PTCH and ROR2 genes identified by genome-wide array-CGH. Am J Med Genet Part A 143A:1885-1889

Paulson KG, Lemos BD, Feng B, Jaimes N, Peñas PF, Bi X, Maher E, Cohen L, Leonard JH, Granter SR, Chin L, Nghiem P (2009) Array-CGH reveals recurrent genomic changes in Merkel cell carcinoma including amplification of L-Myc. J Invest Dermatol 129:1547-1555

Perou CM, Sørlie T, Eisen MB, van de Rijn M, Jeffrey SS, Rees CA, Pollack JR, Ross $D T$, Johnsen $H$, Akslen LA, Fluge O, Pergamenschikov A, Williams C, Zhu SX, Lønning PE, Børresen-Dale AL, Brown PO, Botstein D (2000) Molecular portraits of human breast tumours. Nature 406(6797):747-752

Pirker C, Lötsch D, Spiegl-Kreinecker S, Jantscher F, Sutterlüty H, Micksche M, Grusch M, Berger W (2010) Response of experimental malignant melanoma models to the pan-Aurora kinase inhibitor VE-465. Exp Dermatol 19(12):1040-1047

Rouault A, Banneau G, Macgrogan G, Jones N, Elarouci N, Barouk-Simonet E, Venat L, Coupier I, Letouzé E, de Reyniès A, Bonnet F, lggo R, Sévenet N, Longy M (2012) Deletion of chromosome 13q and 14q is a common feature of tumors with BRCA2 mutations. PLoS One 7(12):e52079. doi:10.1371/journal. pone. 0052079

Rubin Al, Chen EH, Ratner D (2005) Basal cell carcinoma. N Engl J Med 353 (21):2262-2269

Schaefer IM, Enders C, Polten A, Haller F, Frölich AM, Cameron S, Schüler P, Schweiger P, Gunawan B, Beham A, Füzesi L (2011) Common genomic aberrations in basaloid squamous cell carcinoma and carcinosarcoma of the esophagus detected by CGH and array-CGH. Am J Clin Pathol 135:579-586

Silva AG, Ewald IP, Sapienza M, Pinheiro M, Peixoto A, de Nóbrega AF, Carraro DM, Teixeira MR, Ashton-Prolla P, Achatz MI, Rosenberg C, Krepischi AC (2012) Li-Fraumeni-like syndrome associated with a large BRCA1 intragenic deletion. BMC Cancer 12:237

Simpson JF, Gray R, Dressler LG, Cobau CD, Falkson Cl, Gilchrist KW, Pandya KJ, Page DL, Robert NJ (2000) Prognostic value of histologic grade and proliferative activity in axillary node-positive breast cancer: results from the Eastern Cooperative Oncology Group Companion Study, EST 4189. J Clin Oncol 18(10):2059-2069

Sørlie T, Perou CM, Tibshirani R, Aas T, Geisler S, Johnsen H, Hastie T, Eisen MB, van de Rijn M, Jeffrey SS, Thorsen T, Quist H, Matese JC, Brown PO, Botstein D, Lønning PE, Børresen-Dale AL (2001) Gene expression patterns of breast carcinomas distinguish tumor subclasses with clinical implications. Proc Nat Acad Sci U S A 98(19):10869-10874

Xu K, Mao X, Mehta M, Cui J, Zhang C, Xu Y (2012) A comparative study of gene-expression data of basal cell carcinoma and melanoma reveals new insights about the two cancers. PLoS One 7(1):e30750. doi:10.1371/journal. pone. 0030750

Yanaihara N, Nishioka M, Kohno T, Otsuka A, Okamoto A, Ochiai K, Tanaka T, Yokota J (2004) Reduced expression of MYO18B, a candidate tumorsuppressor gene on chromosome arm 22q, in ovarian cancer. Int J Cancer 112(1):150-154

Zhang Y, Zhang G, Li J, Tao Q, Tang W (2010) The expression analysis of periostin in human breast cancer. J Surg Res 160(1):102-106

doi:10.1186/2193-1801-3-454

Cite this article as: Morelle et al: Clinical and genetic characterization of basal cell carcinoma and breast cancer in a single patient. SpringerPlus 2014 3:454.

\section{Submit your manuscript to a SpringerOpen ${ }^{\circ}$ journal and benefit from:}

- Convenient online submission

- Rigorous peer review

- Immediate publication on acceptance

- Open access: articles freely available online

- High visibility within the field

- Retaining the copyright to your article

Submit your next manuscript at $\gg$ springeropen.com 